\title{
Effect of division of initial dose on combustion parameters of a dual fuel CI engine
}

\begin{abstract}
Worsening of economic and environmental parameters of a dual fuel engine at partial engine loads results from protracted combustion of leaned gas-air mixture. This leads to reduction of overall efficiency and growth of CO and THC emissions. Such problems are difficult to solve in traction engines due to their frequent operation at partial loads and rapid changes of engine load and rotational speed. Negative effects of leaning of gaseous mixture can be partially diminished through division of initial dose and activation of combustion of gaseous mixture through delayed injection of additional portion of liquid fuel.

In the paper are presented test results of experimental SB3.1 engine run on CNG with divided dose of the Diesel oil. There were analyzed overall efficiency and selected parameters of combustion process. Division of the dose influenced advantageously on parameters of the engine. The overall efficiency increased, while maximal pressure $p_{\text {max }}$, heat release rate $(d Q / d \alpha)_{\max }$ and pressure growth rate $(d p / d \alpha)_{\max }$ decreased. The engine with divided dose operated more smoothly with less noise.
\end{abstract}

Keywords: dose divided, gas, combustion parameters, heat release, ignition delay

\section{Wpływ podziału dawki inicjującej na parametry spalania dwupaliwowego silnika o zapłonie samoczynnym}

\begin{abstract}
Pogorszenie parametrów ekonomiczno-ekologicznych silnika dwupaliwowego przy częściowych obciążeniach wynika z przewlektego spalania zubożonej mieszaniny gaz-powietrze. Prowadzi to do zmniejszenia sprawności ogólnej silnika $i$ wzrostu emisji CO $i$ THC. Problemy te sa trudne do rozwiąania w silnikach trakcyjnych $z$ uwagi na czessta prace przy częściowych obciążeniach oraz szybkie zmiany w czasie obcią̇enia i prędkości obrotowej. Negatywne skutki zubożenia mieszaniny gazowej można częściowo zmniejszyć przez podziat dawki inicjującej $i$ aktywizację spalania mieszaniny gazowej poprzez opóźniony wtrysk dodatkowej porcji paliwa ciekłego.

W pracy przedstawiono wyniki badań silnika badawczego SB3.1 zasilanego CNG i dzielona dawka oleju napędowego. Analizie poddano sprawność ogólnq i wybrane parametry spalania. Podziat dawki korzystnie wplynąt na parametry silnika. Sprawność silnika wzrosła, natomiast zmniejszeniu uległy ciśnienie maksymalne $p_{\text {max }}$ szybkość wydzielania ciepta $(d Q / d \alpha)_{\text {max }}$, szybkość przyrostu ciśnienia $(d p / d \alpha)_{\max }$. Silnik z dzielona dawka pracowat bardziej równomiernie $i$ wykazywat mniejsza hałaśliwość.

Słowa kluczowe: podziat dawki paliwa, gaz, parametry spalania, wywiazywanie ciepła, opóźnienie zapłonu
\end{abstract}

\section{Introduction}

Excessive worsening of engine parameters at partial loads belongs to important disadvantages of gaseous engines operated in dual fuel system. It results from prolonged combustion of lean mixtures at qualitative adjustment of the engine [1-4]. In result, overall efficiency of the engine at low loads is lower comparing to operation on the Diesel oil only $[1,2$, $10-12,16,18]$. Improved combustion of the lean gaseous mixtures can be attained through:

- reduction of the initial dose,

- partial choking of air at low loads,

- division of the initial dose.

Investigations performed in the Department of Combustion Engines and Vehicles have shown that in case of dual fuel engines, in which interchangeability of fuelling with the Diesel oil only run in dual fuel system is maintained, it is not possible to drastically reduce the initial dose [5-9]. The reasons are inequality and decay of dosage of injectors at small doses. These phenomena concern both classical piston pumps and common rail systems.

\section{Wprowadzenie}

Poważną wadą gazowych silników dwupaliwowych jest nadmierne pogorszenie parametrów przy częściowych obciążeniach. Wynika ono z przedłużającego się spalania ubogich mieszanin gazowych przy jakościowej regulacji silnika [1-4]. W efekcie sprawność ogólna silnika przy małych obciążeniach jest mniejsza w stosunku do zasilania samym olejem napędowym [1,2, 10-12, 16, 18]. Polepszenie spalania ubogich mieszanin gazowych może być osiągane przez zastosowanie:

- zmniejszania dawki inicjującej,

- częściowe dławienie powietrza przy małych obciążeniach, - podział dawki inicjującej.

Badania przeprowadzone w Katedrze Silników Spalinowych i Pojazdów wykazały, że w silnikach dwupaliwowych, w których zachowuje się zamienność zasilania samym olejem napędowym i dwupaliwowo, nie można radykalnie zmniejszyć dawki inicjującej [5-9]. Powodem tego jest nierównomierność i zanik dawkowania wtryskiwaczy przy małych dawkach. Zjawiska te dotyczą 
Moreover, choking of air is strongly restricted due to reduction of temperature during compression, worsening of self-ignition conditions of the initial dose and growth of exhaust gases temperature, threatening durability of turbocompressor systems $[3,4]$.

Performed investigations have shown, that a good solution to improve combustion of the gaseous mixtures could be usage of additional post-injection of the Diesel oil during combustion of the gaseous mixtures $[6,13,14,15]$. Additional liquid fuel, injected during active combustion with delay, immediately goes into oxidation reaction, and supplying additional portion of energy, activates fading combustion process of the gas. Properly selecting size of the initial dose and time of its delay, it is possible to control combustion run of the gaseous mixture. Simulation tests performed prior the tests on engine dynamometer had confirmed such assumptions [17].

Use of injection systems of common rail type controlled electronically enables easy division of the initial dose and optimization of the process according to arbitrary chosen criterion of the optimization.

In course of performed investigations, the dose of the Diesel oil was divided into two equal parts injected in different time, what is schematically illustrated in the Fig. 1. The first dose initiated ignition of the gas, the second dose injected with delay $\Delta \alpha$ delivered additional energy, activating process of combustion of the gas.

In course of the investigations there were arbitrary taken two delay angles $10^{\circ} \mathrm{CA}$ and $15^{\circ} \mathrm{CA}$, basing on preliminary testing of the engine operated at engine speed $1400 \mathrm{rpm}$, corresponding to rotational speed of maximal torque. These angles were constant for complete range of changes of the engine loads and rotational speeds.

The injection advance angle was maintained constant $\Theta_{\text {ww }}=22^{\circ} \mathrm{CA}$ before TDC, the same like in case Diesel oil fuelling, when high pressure common rail system is used.

Taking into considerations the injection advance angle of the initial dose $\theta_{\mathrm{ww}}$, self-ignition delay angle $\theta_{\mathrm{oz}}$ and injection delay of the additional dose $\Delta \alpha$, time-dependent relationships of combustion of the individual doses can be characterized in the way shown in the Fig. 1. Moreover, in connection with it, one took assumption that combustion of the Diesel oil from the second dose commences together with injection of the fuel, what results from ongoing process of active combustion and high temperatures of the reagents (good atomization of the fuel and negligible low delay angle of self-ignition). In the investigations presented hereinafter one also assumed that combustion of the gas commences simultaneously with beginning of combustion of the first dose of the Diesel oil. In practice, it can be delayed with induction angle resulted from progress of flame propagation in the gaseous mixture, dependent on its composition (at big air excess number that angle could be noticeable) [18]. Values of the angles $\Delta \alpha_{1}$, $\Delta \alpha, \Delta \alpha_{2}$ were calculated on the base of opening times of injectors, determined in engine dyno tests and on the basis of analyzed rotational speed, whereas values of the $\Delta \alpha_{1}=$ $\Delta \alpha_{2}$ are dependent from size of the initial dose $q$. zarówno klasycznych pomp łłoczkowych jak i układów common rail.

Również dławienie powietrza jest silnie ograniczone z uwagi na zmniejszenie temperatury w czasie sprężania, pogorszenie warunków samozapłonu dawki inicjującej oraz wzrost temperatury spalin zagrażający trwałości układów turboładowarki $[3,4]$.

Przeprowadzone badania pokazały, że dobrym rozwiązaniem poprawy spalania mieszanin gazowych może być zastosowanie dodatkowego dotrysku oleju napędowego w czasie spalania mieszanin gazowych $[6,13,14,15]$. Dodatkowe paliwo ciekłe, wtryskiwane z opóźnieniem w trakcie aktywnego spalania, wchodzi natychmiast w reakcje utleniania i dostarczając dodatkowej porcji energii aktywizuje zanikający proces spalania gazu. Przez odpowiedni dobór wielkości dawki dodatkowej i czasu jej opóźnienia można sterować przebiegiem spalania mieszaniny gazowej. Badania symulacyjne wykonane przed badaniami hamownianymi potwierdziły te założenia [17].

Zastosowanie układów wtryskowych typu common rail sterowanych elektronicznie umożliwia łatwy podział dawki inicjującej i optymalizację procesu wg dowolnie obranego kryterium optymalizacji.

W przeprowadzonych badaniach dawka oleju napędowego była dzielona na dwie równe części wtryskiwane w różnym czasie, co schematycznie przedstawiono na rys. 1. Pierwsza dawka inicjowała zapłon gazu, a druga wtryskiwana z opóźnieniem $\Delta \alpha$ dostarczała dodatkowej energii aktywizującej proces spalania gazu.

W badaniach stosowano dwa arbitralnie przyjęto kąty opóźnienia $10{ }^{\circ} \mathrm{OWK}$ i $15{ }^{\circ} \mathrm{OWK}$ na podstawie badań wstępnych silnika pracującego przy prędkości obrotowej $1400 \mathrm{obr} / \mathrm{min}$ odpowiadającej prędkości maksymalnego momentu obrotowego. Kąty te były stałe dla całego zakresu zmian obciążenia silnika i prędkości obrotowej.

Kąt wyprzedzenia wtrysku był stały $\Theta_{\mathrm{ww}}=22{ }^{\circ} \mathrm{OWK}$ przed GMP, taki jak przy zasilaniu samym olejem napędowym silnika z wykorzystaniem wysokociśnieniowego systemu common rail.

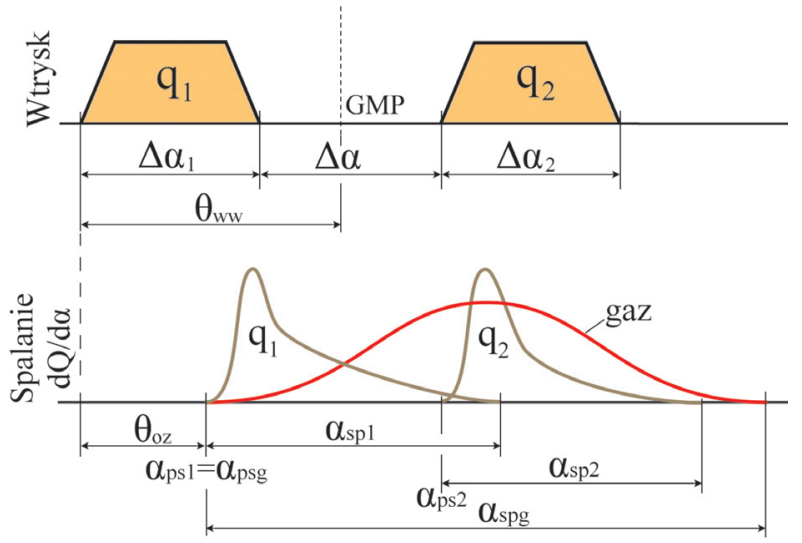

Fig. 1. Scheme of injection of the Diesel oil and combustion of the fuels in dual fuel engine with division of the initial dose

Rys. 1. Schemat wtrysku oleju napędowego i spalania paliw w silniku dwupaliwowym z podziałem dawki inicjujacej 


\section{Test bed}

The investigations were performed on single cylinder, self-ignition experimental engine with direct injection of the SB3.1 type, produced by WSK Mielec. Technical data of the engine are listed in the Table 1.

Table 1. Technical data of the SB3.1 engine

Tabela 1. Dane techniczne silnika SB3.1

\begin{tabular}{|c|c|}
\hline Number of cylinders/liczba cylindrów & 1 \\
\hline Bore/średnica cylindra & $127 \mathrm{~mm}$ \\
\hline Stroke/skok tłoka & $146 \mathrm{~mm}$ \\
\hline Displacement volume/objętość skokowa & $1848 \mathrm{~cm}^{3}$ \\
\hline Compression ratio/stopień sprężania & 15.8 \\
\hline Rated power/moc znamionowa & $22.8 \mathrm{~kW}$ \\
\hline $\begin{array}{l}\text { Engine speed of rated power/prędkość } \\
\text { obrotowa mocy znamionowej }\end{array}$ & $2200 \mathrm{rpm} / \mathrm{obr} / \mathrm{min}$ \\
\hline $\begin{array}{l}\text { Type of combustion chamber/typ komo- } \\
\text { ry spalania }\end{array}$ & $\begin{array}{l}\text { Direct injection to toroidal } \\
\text { chamber in piston crown/ } \\
\text { wtrysk bezpośredni do } \\
\text { toroidalnej komory w ttoku }\end{array}$ \\
\hline $\begin{array}{l}\text { Injection system of initial dose/uktad } \\
\text { wtryskowy dawki inicjujacej }\end{array}$ & $\begin{array}{l}\text { Common Rail, produced } \\
\text { by Bosch/Common Rail } \\
f-m y \text { Bosch }\end{array}$ \\
\hline $\begin{array}{l}\text { Diesel oil injector, produced by Bosch/ } \\
\text { wtryskiwacz ON firmy Bosch }\end{array}$ & 0986435004090 \\
\hline $\begin{array}{l}\text { CNG injection system/uktad wtryskowy } \\
\text { CNG }\end{array}$ & IC \\
\hline $\begin{array}{l}\text { Injector of gas, produced by Bosch/ } \\
\text { wtryskiwacz gazu Bosch }\end{array}$ & F465 15172 \\
\hline $\begin{array}{l}\text { Injection pressure of gas/ciśnienie } \\
\text { wtrysku gazu }\end{array}$ & $1 \mathrm{MPa}$ \\
\hline
\end{tabular}

\section{Analysis of test results}

Division of dose of the Diesel oil advantageously effects on overall efficiency of the engine, what is shown in the Fig. 3. Tendency to increase the efficiency occurs in complete range of change of engine loads, with clear increase of differences of the efficiency in range of medium and maximal engine loads. Simultaneously, increase of delay angle of the additional dose from $10{ }^{\circ} \mathrm{CA}$ to $15^{\circ} \mathrm{CA}$ slightly influenced on reduction of the efficiency.

As especially advantageous can be recognized phenomenon of increase of the efficiency in area of partial engine loads, where traction engines predominantly operate. It is worth to be underlined, that size of the investigated engine lies within size of group of engines used as power units in buses, trucks and mills. Improvement of the efficiency in area of partial loads, therefore, can contribute to reduction of energy consumption in such engines, and globally to considerable reduction of $\mathrm{CO}_{2}$ emission due to huge number of engines operated in roads.

Combustion parameters were calculated on the base of indication diagrams recorded during the test on chassis dyno in steady conditions of engine operation, Mo-n. To the analysis one used averaged indication diagrams from 100 successive cycles of engine operation. In the calculations one used proprietary program to thermal analysis, called
Uwzględniając kąt wyprzedzenia wtrysku dawki inicjującej $\theta_{\text {ww }}$, kąt opóźnienia samozapłonu $\theta_{\text {oz }}$ oraz opóźnienia wtrysku dawki dodatkowej $\Delta \alpha$, czasowe zależności spalania poszczególnych dawek mogą być charakteryzowane jak na rys. 1. przyjęto przy tym założenie, że spalanie ON z drugiej dawki rozpoczyna się wraz z wtryskiem paliwa co wynika z trwającego procesu aktywnego spalania i wysokich temperatur reagentów (dobre rozpylenie paliwa i pomijalnie mały kąt zwłoki samozapłonu). W zaprezentowanych niżej badaniach przyjmowano również, że spalanie gazu rozpoczyna się równocześnie z początkiem spalania pierwszej dawki ON. W rzeczywistości może być ono opóźnione o kąt indukcji wynikający z rozwoju płomienia w mieszaninie gazowej zależny od jej składu (przy dużym współczynniku nadmiaru powietrza kąt ten może być zauważalny) [18]. Wartości kątów $\Delta \alpha_{1}, \Delta \alpha, \Delta \alpha_{2}$ obliczano na podstawie czasów otwarcia wtryskiwaczy określonych $\mathrm{w}$ badaniach hamownianych silnika oraz na podstawie analizowanej prędkości obrotowej, przy czym wartości $\Delta \alpha_{1}=\Delta \alpha_{2}$ zależne są od wielkości dawki inicjującej q.

\section{Stanowisko badawcze}

Badania przeprowadzono na jednocylindrowym silniku badawczym o zapłonie samoczynnym i wtrysku bezpośrednim SB3.1 produkcji WSK Mielec. Dane techniczne silnika przedstawiono $\mathrm{w}$ tabeli 1 .

a)

b)

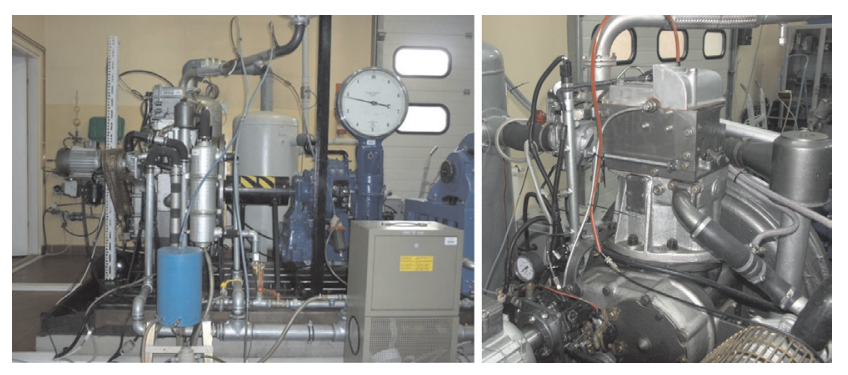

Fig. 2. General view of the test bed

Rys. 2. Widok ogólny stanowiska badawczego

\section{Analiza wyników badań}

Podział dawki oleju napędowego korzystnie wpływa na sprawność silnika, co pokazano na rys. 3. Tendencja zwiększenia sprawności występuje w całym zakresie zmian obciążenia z wyraźnym powiększaniem różnic sprawności w zakresie średnich i maksymalnych obciążeń silnika. Równocześnie zwiększenie kąta opóźnienia dawki dodatkowej z $10{ }^{\circ} \mathrm{OWK}$ do $15^{\circ} \mathrm{OWK}$ nieznacznie wpłynęło na zmniejszenie sprawności.

Za szczególnie korzystne należy uznać zjawisko zwiększenia sprawności w zakresie częściowych obciążeń silnika, przy których silniki trakcyjne pracują najczęściej. Warto podkreślić, że wielkość badanego silnika mieści się w grupie silników stosowanych do napędu autobusów, samochodów ciężarowych i maszyn roboczych. Poprawa sprawności w zakresie obciążeń częściowych może zatem przyczynić się 
as ,ZS-ind.2" developed in the Department of Combustion Engines and Vehicles. [18].

Division of Diesel oil's dose significantly influences changes of the cylinder pressure during active combustion, Fig. 4. During initial phase of the combustion, growth of the do obniżenia zużycia energii w tych silnikach, a globalnie do znaczącego obniżenia emisji $\mathrm{CO}_{2}$ z uwagi na dużą liczbę stosowanych silników.

Parametry spalania obliczono na podstawie zarejestrowanych wykresów indykatorowych w czasie badań hamow- a)

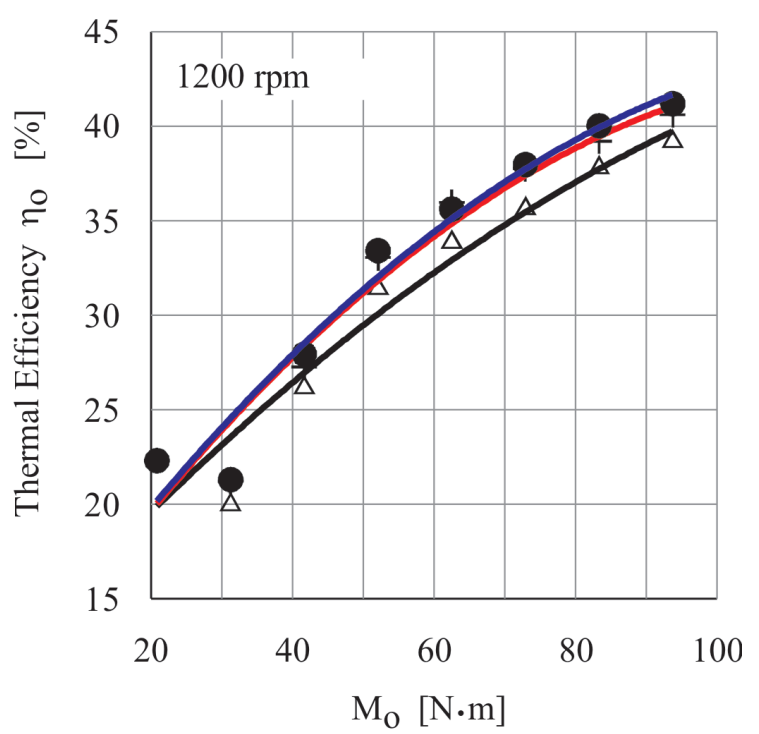

single dose

divided $\Delta \alpha=10^{\circ} \mathrm{CA}$

divided $\Delta \alpha=15^{\circ} \mathrm{CA}$

b)

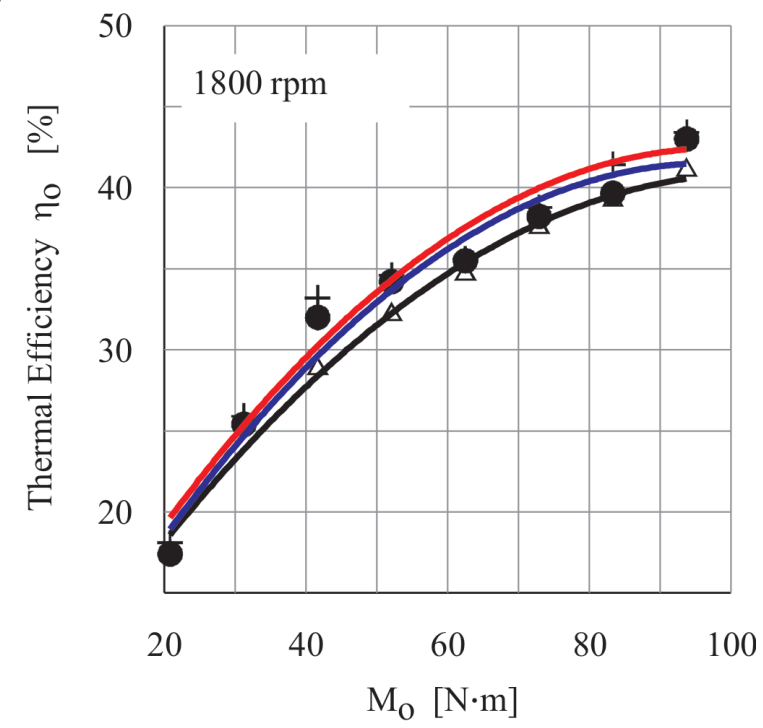

Fig. 3. Effect of division of the Diesel oil dose on efficiency of the SB3.1 engine run in dual fuel system: division of the dose 50/50\%, injection advance angle of the initial dose $22{ }^{\circ} \mathrm{CA}$

Rys. 3. Wpływ podziału dawki oleju napędowego na sprawność silnika SB3.1 zasilanego dwupaliwowo: podziat dawki 50/50\%, kąt wyprzedzenia wtrysku dawki inicjujacej $22^{\circ} \mathrm{OWK}$

pressure in the cylinder for divided doses is lower, and course of the pressure is explicitly shifted in direction of more late angles of crankshaft rotations. Such shift increases as delay angle of the additional dose grows, what is connected with delayed heat release from the Diesel oil. In result, maximal pressures in the cylinder for the divided doses are lower, while angle of their occurrence is delayed with respect to the TDC. Such regularity occurs regardless the engine load.

For delay of additional dose of $15^{\circ} \mathrm{CA}$ is seen a distinct inflexion point on the pressure line, what proves about delay of combustion of the additional dose. The highest delay of pressure maximum occurs for low engine loads and the angle $\Delta \alpha=15^{\circ} \mathrm{CA}$.

In the Fig. 5 is shown a comparison of pressure change in the cylinder for maximal engine load and different engine speeds. In area of higher loads, combustion process of the gaseous mixture is stable, and effect of combustion of the second dose of the Diesel oil is not noticeable in the diagram of the pressure, Fig. 5. It results from low fraction of the additional dose in total quantities supplied to the engine. Increase of engine speed doesn't have any effect on stability of combustion process. However, as engine speed increases, difference in maximal pressures for combustion nianych przy ustalonych warunkach pracy silnika Mo-n. Do analizy wykorzystano uśrednione wykresy indykatorowe ze 100 kolejno po sobie następujących cykli pracy. W obliczeniach zastosowano autorski program obliczeń cieplnych „ZS-ind.2” opracowany w Katedrze Silników Spalinowych i Pojazdów [18].

Podział dawki ON znacząco wpływa na zmiany ciśnienia w cylindrze w czasie aktywnego spalania, rys. 4 . W początkowej fazie spalania wzrost ciśnienia w cylindrze dla dawek dzielonych jest mniejszy a przebieg ciśnienia przesunięty wyraźnie w kierunku późniejszych kątów obrotu wału korbowego. Przesunięcie to zwiększa się w miarę wzrostu kąta opóźnienia dawki dodatkowej, co związane jest z opóźnieniem wydzielania ciepła z ON. W efekcie maksymalne ciśnienia w cylindrze są dla dawek dzielonej mniejsze, a kąt ich występowania jest opóźniony względem GMP. Prawidłowość ta występuje niezależnie od obciążenia silnika.

Dla opóźnienia dawki dodatkowej $15^{\circ} \mathrm{OWK}$ widoczny jest wyraźny punkt przegięcia na linii ciśnienia świadczący o opóźnieniu spalania dawki dodatkowej. Największe opóźnienie maksimum ciśnienia występuje dla małych obciążeń silnika i kąta $\Delta \alpha=15^{\circ} \mathrm{OWK}$. 


$$
\begin{aligned}
& \mathrm{n}=1200 \mathrm{rpm} \\
& \Theta_{\mathrm{ww}}=22{ }^{\circ} \mathrm{CA}
\end{aligned}
$$

a)

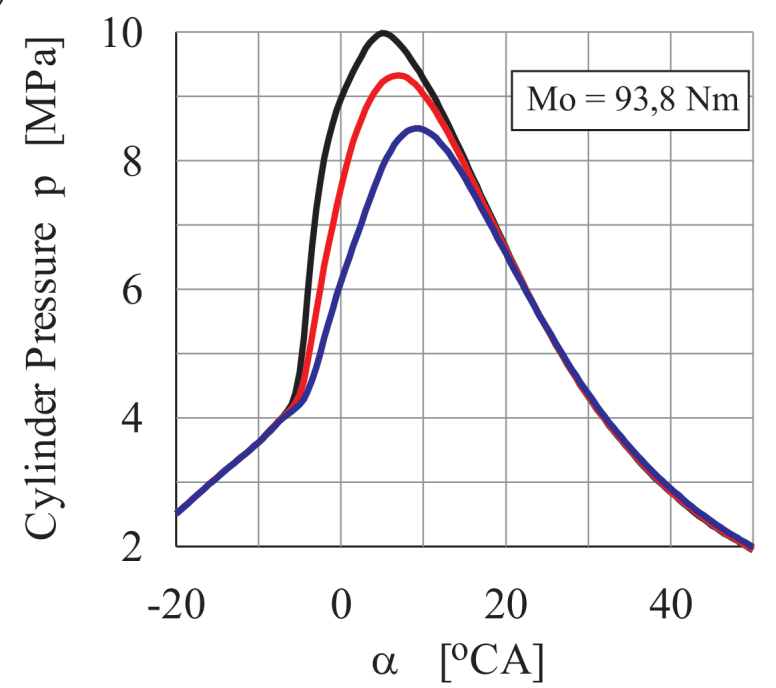

b)

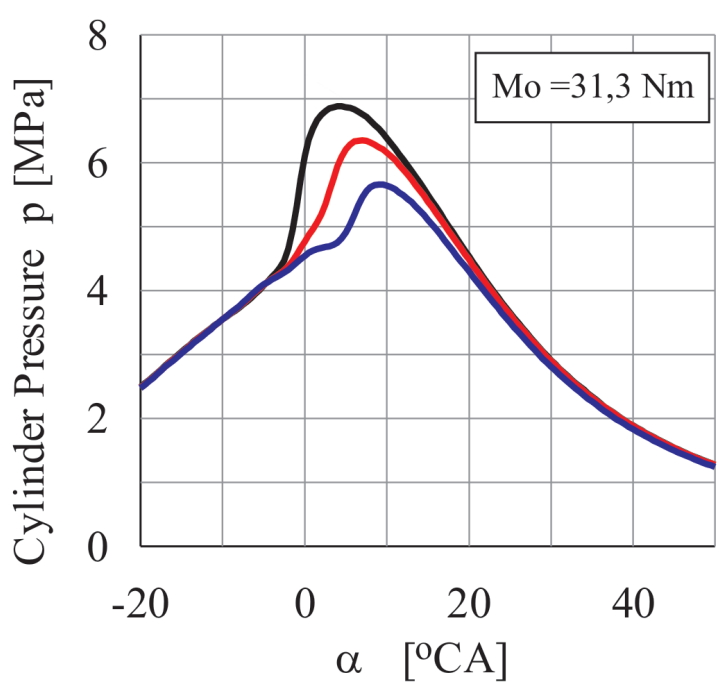

Fig. 4. Change of cylinder pressure during combustion in the SB.1 engine run in dual fuel system, with single and divided initial dose: changing engine load

Rys. 4. Zmiany ciśnienia w cylindrze w czasie spalania w silniku SB.1 zasilanym dwupaliwowo z pojedyncza i dzielona dawka inicjująca: zmienne obciązenie silnika

with single dose and divided doses decreases. Also shift of pressure line at beginning of combustion is smaller for higher rotational speeds. It results from growth of combustion rate of the charge, caused by increase of temperature of working medium at higher rotational speeds.

For all analyzed rotational speeds, cylinder pressures for the divided dose are lower.

Especially big differences in course of the pressure are present for low engine speeds, Fig. 6. Values of the pressure during combustion for divided doses are explicitly delayed, and their maximal values are lower with respect to the single dose. Delay angle of the additional dose $15^{\circ} \mathrm{CA}$ causes occurrence of a distinct inflexion point on pressure line, proving about separate combustion of the both doses. Simultaneously, pressure growth rate after the inflexion point is higher, what can prove about more rapid combustion of the additional dose for delay angle $15^{\circ} \mathrm{CA}$. The phenomena discussed here are similar for all analyzed rotational speeds.

Reduction of maximal combustion pressures effect advantageously on mechanical loading of crankshaft system, what can lead to increase of engine durability. Additional aspect is growth of mechanical efficiency, one from a reasons of discussed earlier growth of the overall efficiency. Lower maximal pressures for the divided doses are present in complete range of investigated rotational speeds and engine loads, Fig. 5 and 6.

As a reason of pressure changes discussed here can be diverse course of combustion of the charge of dual fuel engine with single and divided initial dose. This is evidenced by runs of the heat release rate $\mathrm{dQ} / \mathrm{d} \alpha$ during active combustion, depicted in the Fig. 7-8. Maximal heat release rates in
Na rys. 5 przedstawiono porównanie zmian ciśnienia w cylindrze dla maksymalnego obciążenia silnika i różnych prędkości obrotowych. W zakresie większych obciążeń proces spalania mieszaniny gazowej jest stabilny, a na wykresie ciśnienia niezauważalny jest wpływ spalania drugiej dawki $\mathrm{ON}$, rys. 5. Wynika to z małego udziału energii dawki dodatkowej w całkowitej ilości energii dostarczanej do silnika. Na stabilność procesu spalania nie wpływa wzrost prędkości obrotowej silnika. Jednak w miarę zwiększania prędkości obrotowej maleje różnica ciśnień maksymalnych dla spalania z pojedynczą dawką i dawkami dzielonymi. Również przesunięcie linii ciśnienia na początku spalania jest mniejsze dla większych prędkości obrotowych. Wynika to ze wzrostu szybkości spalania ładunku wywołanego zwiększeniem temperatur czynnika przy większych prędkościach obrotowych.

Dla wszystkich analizowanych prędkości obrotowych ciśnienia w cylindrze są dla dawki dzielonej mniejsze.

Szczególnie duże różnice w przebiegu ciśnień występują dla małych obciążeń silnika rys. 6. Wartości ciśnień w czasie spalania dla dawek dzielonych są wyraźnie opóźnione, a ich wartości maksymalne mniejsze w stosunku do dawki pojedynczej. Kąt opóźnienia dawki dodatkowej 15 ${ }^{\circ} \mathrm{OWK}$ powoduje występowanie wyraźnego punktu przegięcia na linii ciśnienia świadczącego o rozdzielnym spalaniu obu dawek. Równocześnie szybkość narastania ciśnienia za punktem przegięcia jest większa, co może świadczyć o szybszym spalaniu dawki dodatkowej dla kąta opóźnienia $15^{\circ} \mathrm{OWK}$. Omawiane zjawiska są podobne dla wszystkich analizowanych prędkości obrotowych.

Zmniejszenie maksymalnych ciśnień spalania wpływa korzystnie na obciążenia mechaniczne układu korbowego 
a)

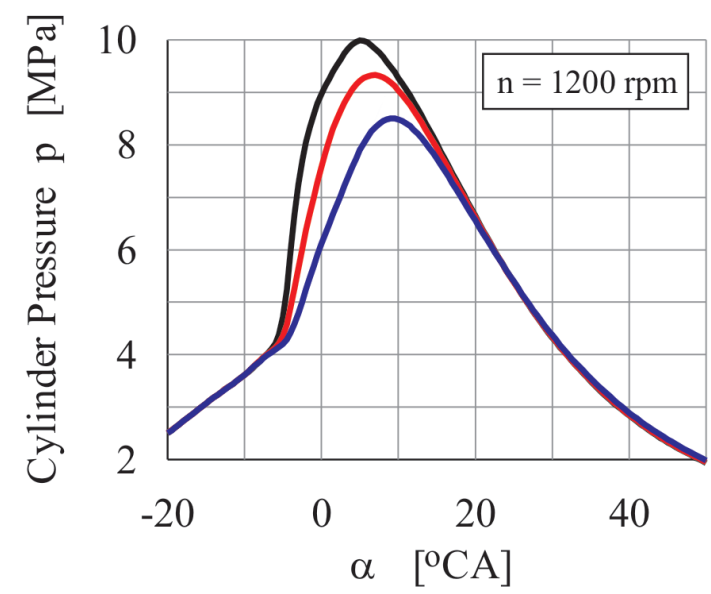

b)

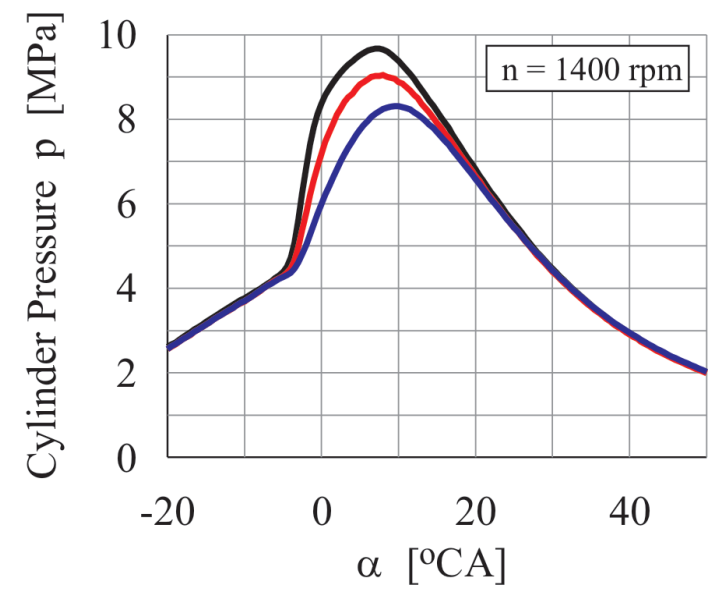

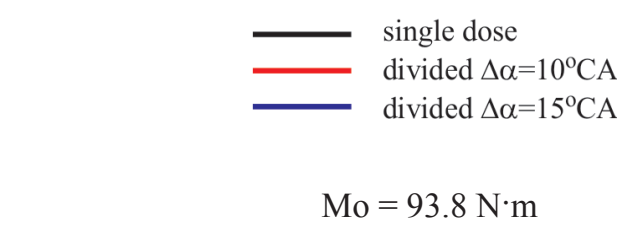

Injection timing $\theta_{\mathrm{ww}}=22^{\circ} \mathrm{CA}$ for TDC

kat wyprzedzenia wtrysku $\theta_{w w}=22^{\circ} \mathrm{OWK}$ przed GMP

Pilot dose quantity/wielkość dawki inicjującej: $1200 \mathrm{rpm}-\mathrm{q}=33.3 \mathrm{~mm}^{3} /$ cycle $1400 \mathrm{rpm}-\mathrm{q}=31.4 \mathrm{~mm}^{3} /$ cycle $1600 \mathrm{rpm}-\mathrm{q}=28.8 \mathrm{~mm}^{3} /$ cycle

c)

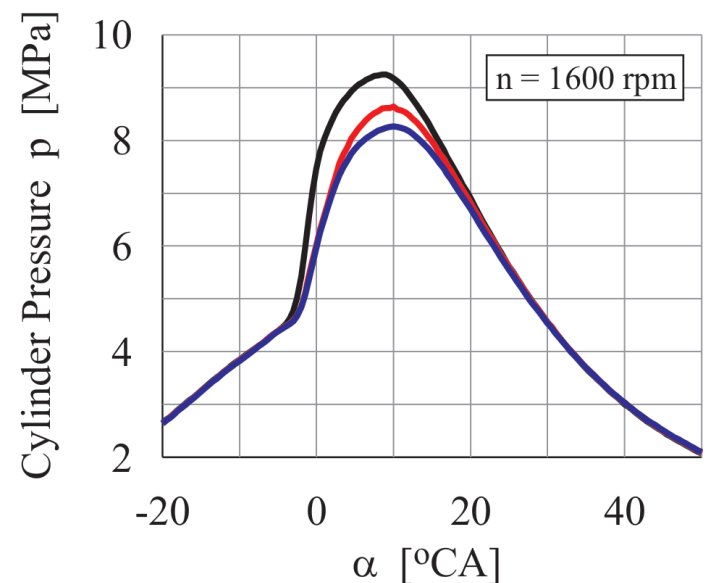

Fig. 5. Effect of division of initial dose on run of cylinder pressure during combustion in the SB3.1 engine, run in dual fuel system: maximal engine load $(\mathrm{Mo}=93.8 \mathrm{~N} \cdot \mathrm{m}$, changing engine speeds $1200,1400,1600 \mathrm{rpm})$

Rys. 5. Wplyw podziału dawki inicjującej na przebieg ciśnienia w cylindrze podczas spalania w silniku SB3.1 zasilanym dwupaliwowo: maksymalne obciążenie silnika (Mo =93,8 N·m, zmienne prędkości obrotowe 1200, 1400, $1600 \mathrm{obr} / \mathrm{min}$

case of the divided doses are clearly lower than in case of combustion with single dose. Simultaneously, the angles $\mathrm{dQ} / \mathrm{d} \alpha$ are shifted in the right side, towards more late angles of crankshaft rotations, the more the bigger delay angle of additional dose.

Together with growth of rotational speed, maximal values of the $\mathrm{dQ} / \mathrm{d} \alpha$ for the single dose decrease, while point of its occurrence delays, approaching to the TDC, Fig. 7. Maximal dynamics of the combustion for the single dose occurs before the TDC. Data from the bibliography show, that the engines run on the Diesel oil only develop maximal efficiency when maximal dynamics of the combustion is present in range of 2-4 ${ }^{\circ} \mathrm{CA}$ after the TDC.

In case of high injection pressures and single dose, total amount of liquid fuel is injected before commencing of the combustion. Initial dose is small comparing to the doses in traditional fuelling. In conditions of high temperatures of the charge (engine loads similar to maximal ones, Fig. 7) all the fuel evaporates during time of self-ignition delay. In case of multipoint self-ignition in zone of liquid fuel vapours, run of the combustion is violent, and its rate is defined by kinetics of chemical reactions. Combustion of co może prowadzić do zwiększenia trwałości silnika. Dodatkowym aspektem jest wzrost sprawności mechanicznej, jednego z powodów omawianego wcześniej wzrostu sprawności ogólnej. Mniejsze ciśnienia maksymalne dla dawek dzielonych występują w całym zakresie badanych zmian prędkości obrotowej i obciążenia silnika - rys. 5 i 6 .

Przyczyną omawianych zmian ciśnienia jest odmienny przebieg spalania ładunku silnika dwupaliwowego z pojedynczą i dzieloną dawką inicjującą. Świadczą o tym przebiegi szybkości wydzielania ciepła $\mathrm{dQ} / \mathrm{d} \alpha$ w czasie aktywnego spalania pokazane na rys. 7-8. Maksymalne szybkości wydzielania ciepła dla dawek dzielonych są wyraźnie mniejsze od spalania z dawką pojedynczą. Równocześnie krzywe dQ/d $\alpha$ są przesunięte w prawo, w stronę późniejszych kątów OWK, tym bardziej im większy jest kąt opóźnienia dawki dodatkowej.

W miarę wzrostu prędkości obrotowej maksymalna wartość $\mathrm{dQ} / \mathrm{d} \alpha$ dla dawki pojedynczej maleje, a punkt jej występowania opóźnia się, zbliżając się do GMP, rys. 7. Maksymalna dynamika spalania dla dawki pojedynczej występuje przed GMP. Dane literaturowe wskazują, że silniki zasilane samym olejem napędowym osiągają maksymalną 
a)

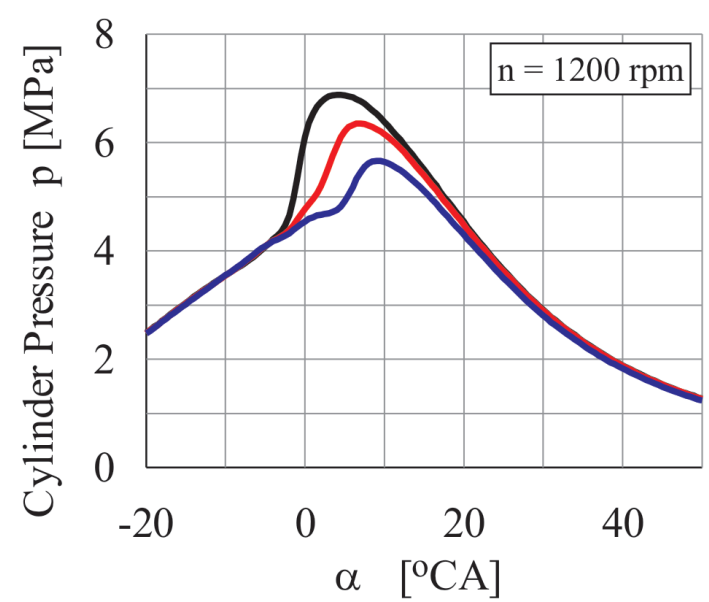

b)

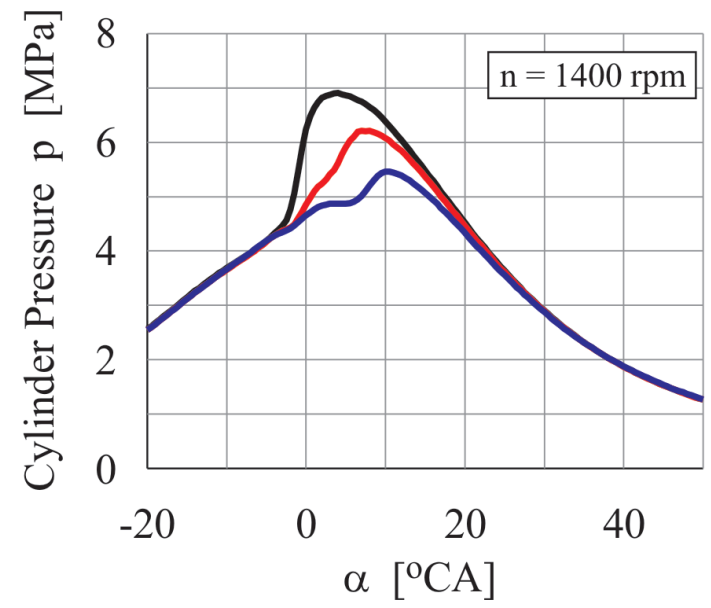

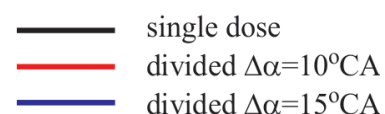

$\mathrm{Mo}=31.3 \mathrm{~N} \cdot \mathrm{m}$

Injection timing $\theta_{\mathrm{ww}}=22{ }^{\circ} \mathrm{CA}$ for TDC kat wyprzedzenia wtrysku $\theta_{w w}=22^{\circ} \mathrm{OWK}$ przed GMP

Pilot dose quantity/wielkość dawki inicjującej: $1200 \mathrm{rpm}-\mathrm{q}=33.3 \mathrm{~mm}^{3} /$ cycle $1400 \mathrm{rpm}-\mathrm{q}=31.4 \mathrm{~mm}^{3} /$ cycle $1600 \mathrm{rpm}-\mathrm{q}=28.8 \mathrm{~mm}^{3} /$ cycle

c)

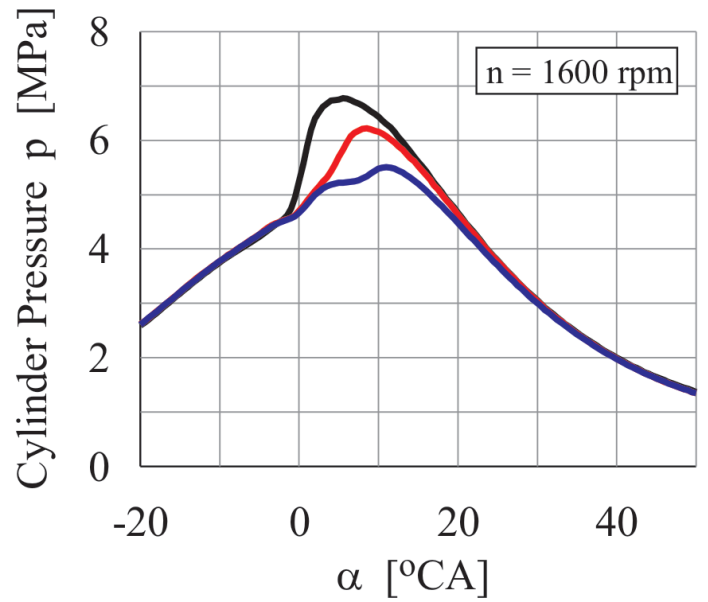

Fig. 6. Effect of division of initial dose on course of cylinder pressure during combustion in the SB3.1 engine run in dual fuel system: engine load $\mathrm{Mo}=31.3 \mathrm{~N} \cdot \mathrm{m}$ (variable engine speeds 1200, 1400, $1600 \mathrm{rpm}$ )

Rys. 6. Wpływ podziału dawki inicjującej na przebieg ciśnienia w cylindrze podczas spalania w silniku SB3.1 zasilanym dwupaliwowo: obciążenie silnika Mo $=31,3 \mathrm{~N} \cdot \mathrm{m}$, zmienne prędkości obrotowe $1200,1400,1600 \mathrm{obr} / \mathrm{min}$

liquid fuel vapours is accompanied with high maximal values of the $\mathrm{dQ} / \mathrm{d} \alpha$.

In case of single dose, maximal value of the $\mathrm{dQ} / \mathrm{d} \alpha$ effects from combustion of liquid fuel, what results from significant differences of combustion rate of the Diesel oil (multipoint kinetic combustion) and gaseous mixture (combustion determined by speed of moving front of flame with relatively low speed).

In case of the divided dose, similar phenomena occur only for the first initial dose; however, lower unit mass of this dose doesn't allow releasing of energy sufficient to generate similar values of the $\mathrm{dQ} / \mathrm{d} \alpha$ like in case of the single dose. The second dose enters into combustion process much faster, but this process occurs mainly in phase of diffusion combustion. Simultaneously, growth of the combustion rate after local minimum in the curves $d Q / d \alpha$ and shift of the curves to the right, especially clearly seen in case of lean mixtures (Fig. 7), and bigger values of the $\mathrm{dQ} / \mathrm{d} \alpha$ during more late phases of the process, than these ones in case of the single dose, can prove about bigger share of energy from combustion of the gaseous mixture and increasing of rate of the process by the additional dose. sprawność, jeżeli maksymalna dynamika spalania występuje w zakresie $2-4{ }^{\circ} \mathrm{OWK}$ po GMP.

Przy dużych ciśnieniach wtrysku i pojedynczej dawce cała ilość paliwa ciekłego wtryskiwana jest przed rozpoczęciem spalania. Dawka inicjująca jest niewielka w stosunku do dawek przy zasilaniu tradycyjnym. W warunkach wysokich temperatur ładunku (obciążenia zbliżone do maksymalnych, rys. 7) cała ilość paliwa odparowuje w okresie opóźnienia samozapłonu. Przy wielopunktowym samozapłonie w strefach par paliwa ciekłego, przebieg spalania jest gwałtowny, jego szybkość jest określona kinetyką reakcji chemicznych. Spalaniu par paliwa ciekłego towarzyszą duże wartości maksymalne $\mathrm{dQ} / \mathrm{d} \alpha$.

Dla dawki pojedynczej maksymalna wartość $d Q / d \alpha$ wynika ze spalania paliwa ciekłego, co wynika z istotnych różnic szybkości spalania oleju napędowego (wielopunktowe spalanie kinetyczne) i mieszaniny gazowej (spalanie determinowane przez szybkość przemieszczania się frontu płomienia o relatywnie małej szybkości).

Dla dawki dzielonej podobne zjawiska występują jedynie dla pierwszej dawki inicjującej, ale mniejsza masa 
a)

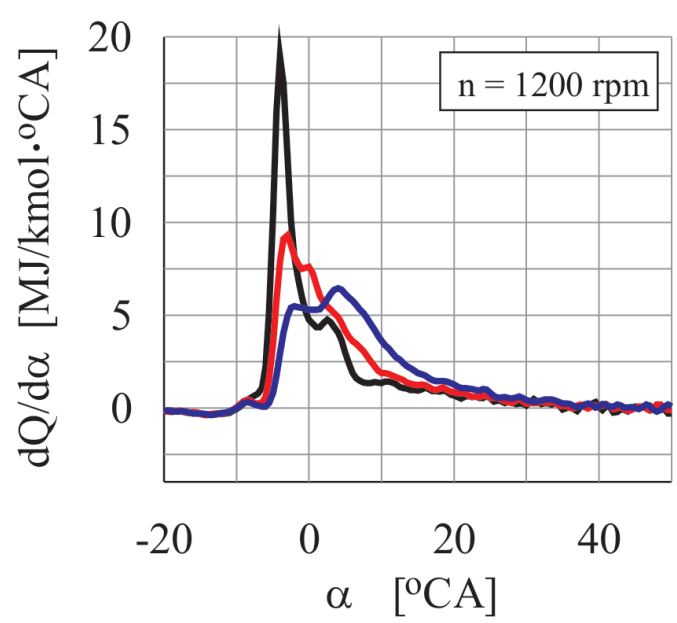

b)

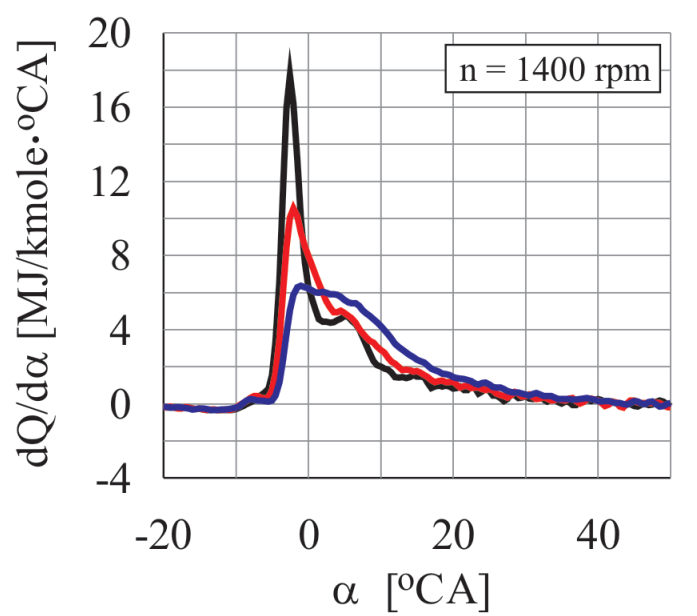

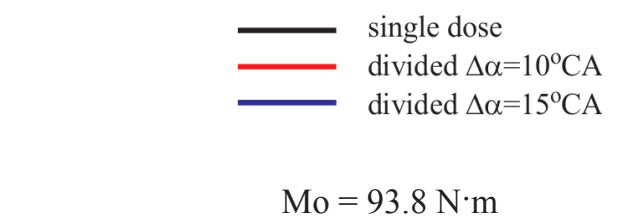

Injection timing $\theta_{\mathrm{ww}}=22^{\circ} \mathrm{CA}$ for TDC kat wyprzedzenia wtrysku $\theta_{w w}=22^{\circ} \mathrm{OWK}$ przed GMP

Pilot dose quantity/wielkość dawki inicjującej: $1200 \mathrm{rpm}-\mathrm{q}=33.3 \mathrm{~mm}^{3} /$ cycle $1400 \mathrm{rpm}-\mathrm{q}=31.4 \mathrm{~mm}^{3} /$ cycle $1600 \mathrm{rpm}-\mathrm{q}=28.8 \mathrm{~mm}^{3} /$ cycle

c)

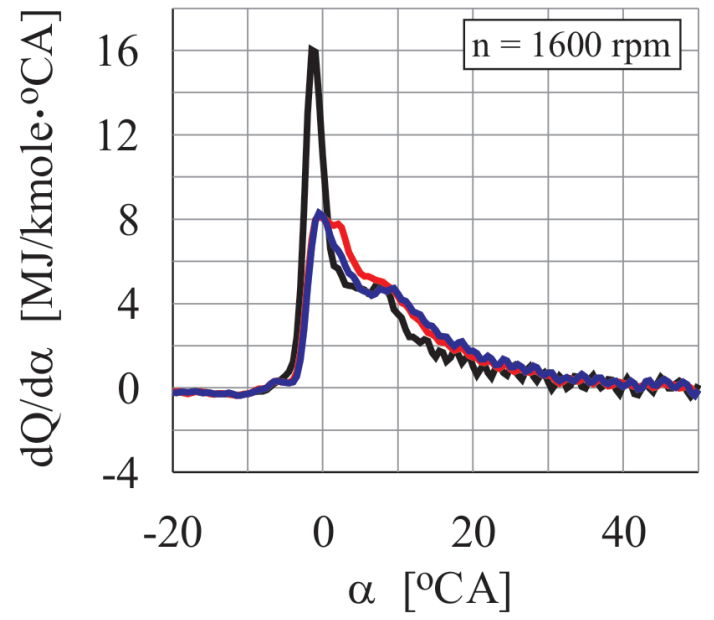

Fig. 7. Effect of division of initial dose on run of the heat release rate $d Q / d \alpha$ during combustion in the SB3.1 engine run in dual fuel system: maximal load $\mathrm{Mo}=93.8 \mathrm{~N} \cdot \mathrm{m}$

Rys. 7. Wpływ podziału dawki inicjującej na przebieg szybkości wydzielania ciepła dQ/da podczas spalania w silniku SB3.1 zasilanym dwupaliwowo: maksymalne obciażenie silnika $M o=93,8 \mathrm{~N} \cdot \mathrm{m}$

For low engine loads (Fig. 8) is seen a clear shift of dynamics of the combustion as the injection delay angle of the additional dose increases. For the angle $\Delta \alpha=15^{\circ} \mathrm{CA}$, in the curves $\mathrm{dQ} / \mathrm{d} \alpha$ is present a clear point of local minimum and big differences of maximal $\mathrm{dQ} / \mathrm{d} \alpha$ for the initial and additional dose.

From the equation describing run of the curves $\mathrm{dQ} / \mathrm{d} \alpha$ in the Fig. 7-8 one can conclude about real growth of activity of gaseous mixture combustion after use of the divided dose.

Division of dose of the Diesel oil effects in decrease of maximal pressures $p_{\max }$ and rate of pressure growth $(\mathrm{dp} / \mathrm{d} \alpha)_{\max }$ in complete range of engine loads and rotational speeds, Fig. 9a.

Decrease of the maximal pressure amounted respectively to:

- 0.5-0.7 MPa for the delay angle $10^{\circ} \mathrm{CA}$ and

- 0.9-1.3 MPa for the delay angle $15^{\circ} \mathrm{CA}$.

Specified proportions of change of the maximal pressure are similar regardless of engine load and rotational speed.

Additional, noticeable effect of pressure change after use of the additional dose is more smooth and more silent jednostkowa tej dawki nie pozwala wyzwolić dostatecznej ilości ciepła dla uzyskania podobnych wartości dQ/d $\alpha$ jak dla dawki pojedynczej. Druga dawka wchodzi w proces spalania znacznie szybciej, ale odbywa się on głównie w fazie spalania dyfuzyjnego. Równocześnie wzrost szybkości spalania po wystąpieniu minimum lokalnego na krzywych $\mathrm{dQ} / \mathrm{d} \alpha$ i przesunięcie ich w prawo, szczególnie wyraźnie widoczne dla ubogich mieszanin (rys. 8) oraz większe wartości $\mathrm{dQ} / \mathrm{d} \alpha$ w późniejszych fazach procesu od występujących dla dawki pojedynczej, świadczą o większym udziale energii ze spalania mieszaniny gazowej i zwiększeniu szybkości procesu przez dawkę dodatkową.

Dla małych obciążeń silnika (rys. 8) widoczne jest wyraźne przesunięcie dynamiki spalania wraz ze zwiększaniem kąta opóźnienia wtrysku dawki dodatkowej. Dla kąta $\Delta \alpha=$ $15^{\circ} \mathrm{OWK}$ występuje wyraźny punkt minimum lokalnego na krzywych dQ/d $\alpha$ oraz duże różnice maksymalnej $\mathrm{dQ} / \mathrm{d} \alpha$ dla dawki inicjującej i dodatkowej.

$\mathrm{Z}$ porównania przebiegu krzywych $\mathrm{dQ} / \mathrm{d} \alpha$ na rys. 7-8 można wnioskować o rzeczywistym wzroście aktywności 
a)

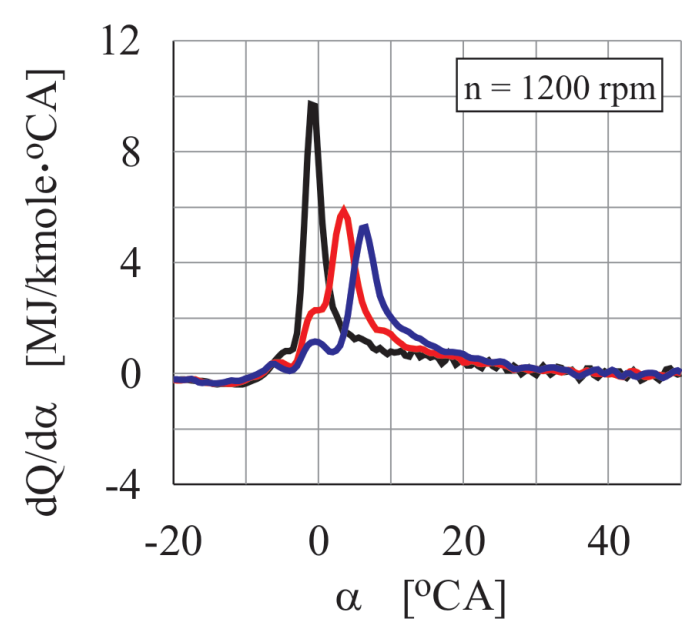

b)

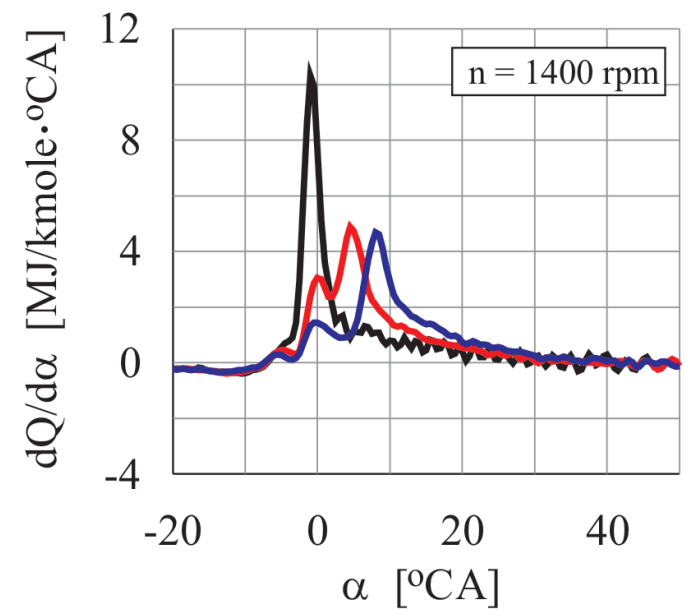

\author{
- single dose \\ - divided $\Delta \alpha=10^{\circ} \mathrm{CA}$ \\ divided $\Delta \alpha=15^{\circ} \mathrm{CA}$ \\ $\mathrm{Mo}=31.3 \mathrm{~N} \cdot \mathrm{m}$ \\ Injection timing $\theta_{w w}=22^{\circ} \mathrm{CA}$ for TDC \\ kat wyprzedzenia wtrysku $\theta_{w w}=22^{\circ} \mathrm{OWK}$ przed GMP
}

pilot dose quantity/wielkość dawki inicjującej:

$1200 \mathrm{rpm}-\mathrm{q}=33.3 \mathrm{~mm}^{3} /$ cycle

$1400 \mathrm{rpm}-\mathrm{q}=31.4 \mathrm{~mm}^{3} /$ cycle

$1600 \mathrm{rpm}-\mathrm{q}=28.8 \mathrm{~mm}^{3} /$ cycle

c)

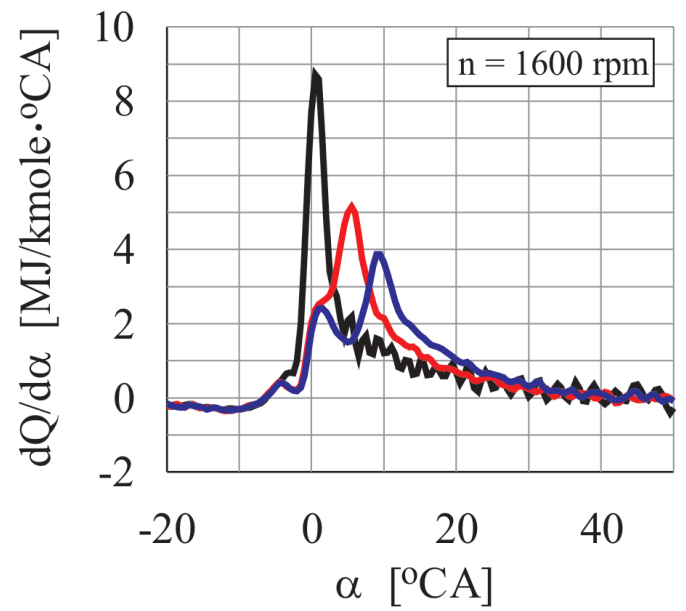

Fig. 8. Effect of division of initial dose on run of the heat release rate $\mathrm{dQ} / \mathrm{d} \alpha$ during combustion in the SB3.1 engine run in dual fuel system: engine load $\mathrm{Mo}=31.3 \mathrm{~N} \cdot \mathrm{m}$

Rys. 8. Wplyw podziału dawki inicjujacej na przebieg szybkości wydzielania ciepła dQ/da podczas spalania w silniku SB3.1 zasilanym dwupaliwowo: częściowe obciążenie silnika Mo $=31,3 \mathrm{~N} \cdot \mathrm{m}$

operation of the engine. Increase of smoothness of engine operation is connected with more stable combustion of the gaseous mixture due to additional portion of energy from combustion of the additional dose, released with delay.

Dual fuel engine fuelled with the divided doses operates more quietly with clearly noticeable less noise. It results mainly from less noise of combustion process, that was confirmed by analyses of pressure growth rates $\mathrm{dp} / \mathrm{d} \alpha$ and maximal $(d p / d \alpha)_{\max }$ shown in the Fig. 9b. Values of the $(\mathrm{dp} / \mathrm{d} \alpha)_{\max }$ for the divided doses are clearly lower, while their values are comparable with values characteristic for spark ignition engines. It also applies to maximal engine loads when combustion of the charge is the fastest. Values of the (dp/ $\mathrm{d} \alpha)_{\max }$ affect perceptible noise of combustion in the engine. In case of the single dose, the $(\mathrm{dp} / \mathrm{d} \alpha)_{\max }$ features values of $0.80-1.4 \mathrm{MPa} /{ }^{\circ} \mathrm{CA}$ what causes that combustion process can be classified as a hard combustion. On the other hand, for the divided doses, values of the $(\mathrm{dp} / \mathrm{d} \alpha)_{\max }$ are included within interval of $0.4-0.6 \mathrm{MPa} /{ }^{\circ} \mathrm{CA}$, which should be considered as low values, as for a self-ignition engine. spalania mieszaniny gazowej po zastosowaniu dawki dzielonej.

Podział dawki ON powoduje zmniejszenie ciśnień maksymalnych $\mathrm{p}_{\max }$ oraz szybkości narastania ciśnienia $(\mathrm{dp} / \mathrm{d} \alpha)$ ${ }_{\max }$ W całym zakresie zmian obciążeń i prędkości obrotowej silnika, rys. 9a.

Zmniejszenie ciśnienia maksymalnego wynosiło odpowiednio:

- 0,5-0,7 MPa dla kąta opóźnienia $10^{\circ} \mathrm{OWK}$ i

- 0,9-1,3 MPa dla kąta opóźnienia $15^{\circ} \mathrm{OWK}$.

Wymienione proporcje zmiany ciśnienia maksymalnego są podobne niezależnie od obciążenia i prędkości obrotowej silnika.

Dodatkowym zauważalnym efektem zmian ciśnienia po zastosowaniu dawki dzielonej jest bardziej równomierna i cichsza praca silnika. Zwiększenie równomierności pracy związane jest z bardziej stabilnym spalaniem mieszaniny gazowej wskutek dodatkowej porcji energii wyzwalanej z opóźnieniem ze spalania dawki dodatkowej. 


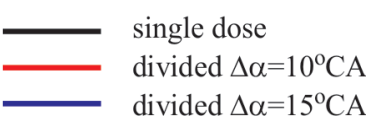

a)

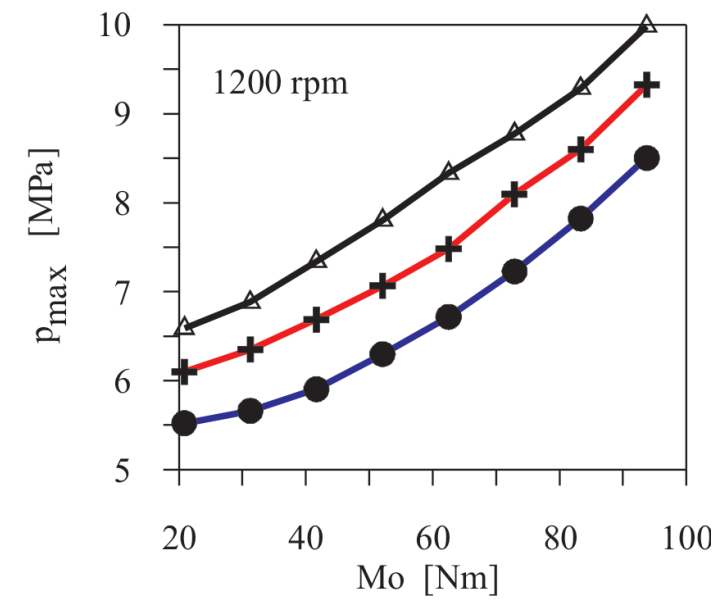

c)

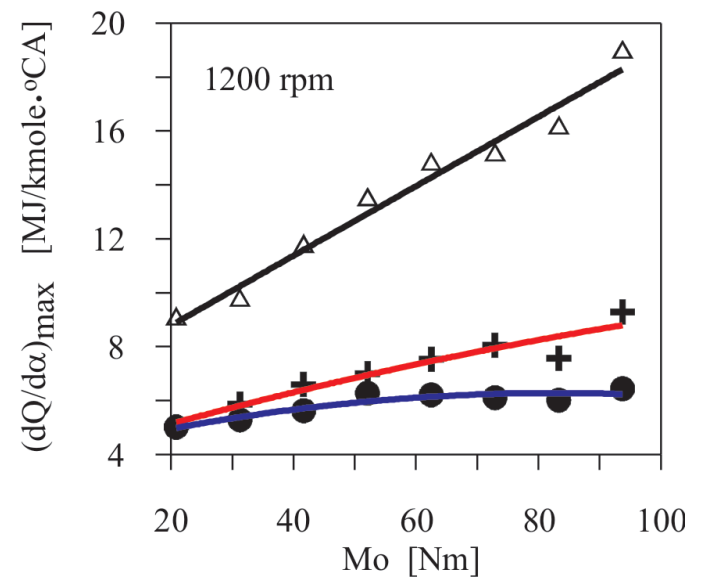

b)

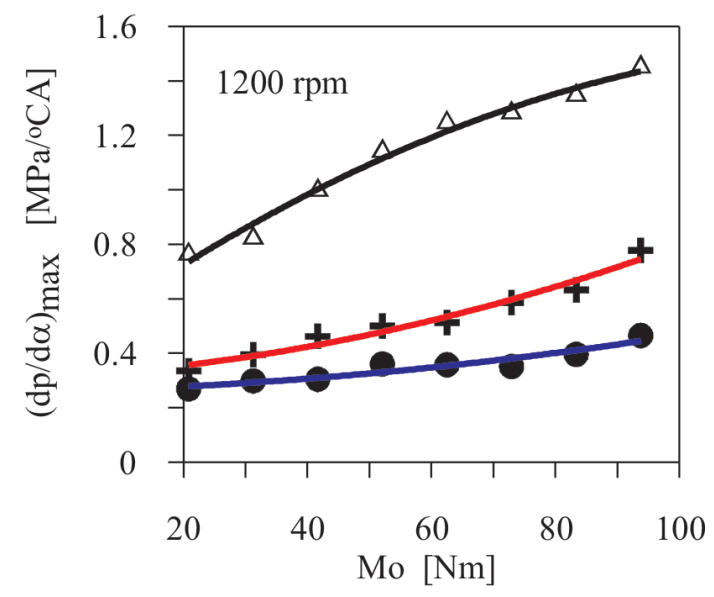

d)

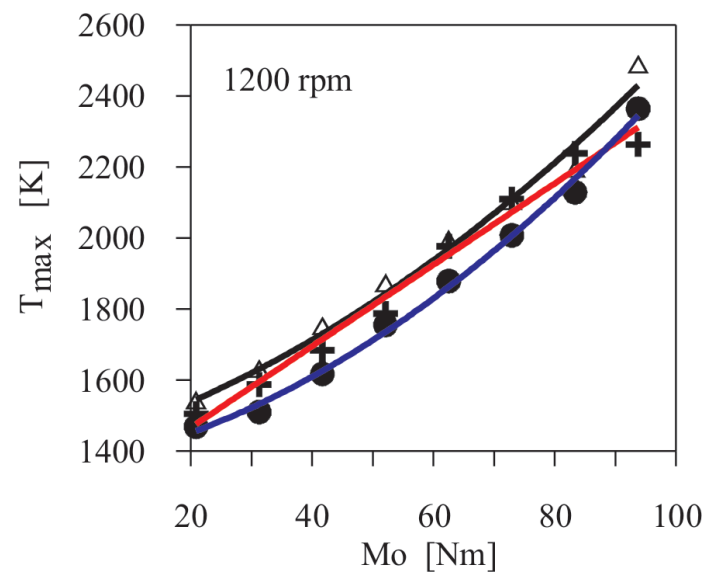

Fig. 9. Effect of division of the dose on maximal parameters of combustion in the SB3.1 engine run in dual fuel system: maximal pressure $\mathrm{p}_{\max }$, rate of pressure growth $(\mathrm{dp} / \mathrm{d} \alpha)_{\max }$, heat release rate $(\mathrm{dQ} / \mathrm{d} \alpha)_{\max }$, temperature of working medium $\mathrm{T}_{\max }$

Rys. 9. Wplyw podziału dawki na maksymalne parametry spalania silnika SB3.1 zasilanego dwupaliwowo: ciśnienie maksymalne $p_{\text {max }}$ szybkość przyrostu ciśnienia $(d p / d \alpha)_{\max }$, szybkość wydzielania ciepła $(d Q / d \alpha)_{\max }$, temperaturę czynnika $T_{\max }$

Phenomenon of reduction of the $(\mathrm{dp} / \mathrm{d} \alpha)_{\max }$ during combustion of the charge with divided doses of the Diesel oil is maintained in complete range of change of engine parameters. Values of the $(\mathrm{dp} / \mathrm{d} \alpha)_{\max }$ for the divided doses are more than twice lower than values for the single dose.

Changes of values of the $(\mathrm{dp} / \mathrm{d} \alpha)_{\max }$ discussed here show at a possibility of reduction of noise in dual fuel engine through division of dose of the Diesel oil. It could have a substantial importance in application of the engines in public transportation, where noise of the engine is very important. Reduction of the noisiness gives additional argument to introduction of division of Diesel oil dose in dual fuel engine.

Comparison of values of the $(\mathrm{dQ} / \mathrm{d} \alpha)_{\max }$ for changing engine loads, Fig. 9c, shows that combustion of the charge with divided doses occurs at values of the $(\mathrm{dQ} / \mathrm{d} \alpha)_{\text {max }}$ nearly twice smaller than in case of the charge with single dose. This regularity is independent from change of working
Silnik dwupaliwowy zasilany dawkami dzielonymi pracuje spokojniej z wyraźnie odczuwalnym mniejszym hałasem. Wynika to głównie z mniejszego hałasu procesu spalania, co potwierdzają analizy szybkości narastania ciśnienia $\mathrm{dp} / \mathrm{d} \alpha$ i wartości maksymalne $(\mathrm{dp} / \mathrm{d} \alpha)_{\max }$ pokazane na rys. 9b. Wartości $(d p / d \alpha)_{\max }$ są dla dawek dzielonych wyraźnie mniejsze, porównywalne do wartości charakterystycznych dla silników o zapłonie iskrowym. Dotyczy to również maksymalnych obciążeń silnika, kiedy spalanie ładunku jest najszybsze. Wartości $(\mathrm{dp} / \mathrm{d} \alpha)_{\max }$ decydują o odczuwalnym hałasie spalania silnika. W przypadku dawki pojedynczej $(\mathrm{dp} / \mathrm{d} \alpha)_{\max }$ mają wartości $0,80-1,4$ $\mathrm{MPa} /{ }^{\circ} \mathrm{OWK}$ co powoduje, że proces spalania można zakwalifikować jako twarde spalanie. Natomiast dla dawek dzielonych wartości $(\mathrm{dp} / \mathrm{d} \alpha)_{\max }$ mieszczą się w przedziale 0,4-0,6 $\mathrm{MPa} /{ }^{\circ} \mathrm{OWK}$ co należy uznać za wartości małe jak dla silnika ZS. 
parameters of the engine and creates characteristic feature of division of dose of liquid fuel. Simultaneously, bigger delay angles are accompanied by smaller values of the $(\mathrm{dQ} / \mathrm{d} \alpha)_{\max }$, and the differences are growing together with growth of engine load.

Smaller values of the $(\mathrm{dQ} / \mathrm{d} \alpha)_{\max }$ for the divided doses have an effect on quantity of the NO generated in exhaust gases, and the same have an effect on reduction of concentration of the $\mathrm{NO}_{\mathrm{v}}$, what was signaled in earlier publications $[11,16,18]$. However, basing on changes of the value of the $(\mathrm{dQ} / \mathrm{d} \alpha)_{\max }$ it is not possible to conclude about emissions of the $\mathrm{NO}_{x}$, because $\mathrm{NO}$ is not generated directly behind zone of flame (locally), while the $\mathrm{dQ} / \mathrm{d} \alpha$ is calculated from global effects of the heat taken by the whole charge. In spite of it, however, one should recognize that relation between values of the $(\mathrm{dQ} / \mathrm{d} \alpha)_{\max }$ and emission of the $\mathrm{NO}_{\mathrm{x}}$ is present, and in case of combustion in dual fuel engine is worth to be investigated.

Division of dose of the Diesel oil results in reduction of average temperature of working medium during active combustion. Lower temperatures in the first phase of combustion are natural consequence of delayed heat release, what has been analyzed earlier, but simultaneously, maximal temperatures of the medium, $\mathrm{T}_{\max }$, are lower in case of divided doses, Fig. 9d. Tendency of reduction of the $\mathrm{T}_{\max }$ is maintained in complete range of change of operational parameters of the engine.

In spite of combustion delay of the additional dose with respect to the TDC and changes in run of the heat release, what was analyzed earlier, division of the dose advantageously effects on average rate of combustion of the charge in range of partial engine loads, what can be proved by decrease of total angle of combustion of the charge, $\alpha_{\mathrm{sp}}$, Fig. 10.

Differences in the combustion angle $\alpha_{\mathrm{sp}}$ at partial engine loads grow in case of higher rotational speeds (1600 rpm). Anyhow, this phenomenon can be recognized as advantageous, because in range of partial engine loads is present a high leaning of the gaseous mixture, which determines rate and completeness of combustion in dual fuel engine. Increase of combustion rate of this mixture, as evidenced by growth of average combustion rate value, expressed by shortened time of the $\alpha_{\mathrm{sp}}$, constituted one from the main assumptions to introduction of divided dose of the Diesel oil.

Simultaneously, it should be noticed that for a bigger engine loads, close to the maximal one, division of the dose can slightly prolong process of the combustion, what can be proved by the runs shown in the Fig. 10. However it is worth to underline, that prolongation of the angle $\alpha_{\mathrm{sp}}$ did not have any negative effect on overall efficiency of the engine, which in area of these loads increased, as well as on exhaust gas temperatures after opening of the exhaust valve.
Zjawisko zmniejszenia $(\mathrm{dp} / \mathrm{d} \alpha)_{\max }$ podczas spalania ładunku z dzielonymi dawkami oleju napędowego utrzymuje się w całym zakresie zmian parametrów pracy silnika. Wartości $(\mathrm{dp} / \mathrm{d} \alpha)_{\max }$ dla dawek dzielonych są ponad dwukrotnie mniejsze od wartości dla dawki pojedynczej.

Omawiane zmiany wartości $(\mathrm{dp} / \mathrm{d} \alpha)_{\max }$ wskazują na możliwości zmniejszenia hałaśliwości silnika dwupaliwowego przez podział dawki ON. Może to mieć istotne znaczenie w zastosowaniach silników do transportu publicznego, gdzie hałaśliwość silnika ma bardzo istotne znaczenie. Zmniejszenie hałaśliwości jest dodatkowym argumentem do wprowadzenia podziału dawki ON w silnikach dwupaliwowych.

Porównanie wartości $(\mathrm{dQ} / \mathrm{d} \alpha)_{\max }$ dla zmiennych obciążeń silnika rys. $9 \mathrm{c}$ wskazuje, że spalanie ładunku przy dawkach dzielonych odbywa się przy wartościach $(\mathrm{dQ} / \mathrm{d} \alpha)_{\max }$ ponad dwukrotnie mniejszych niż ładunku z dawką pojedynczą. Prawidłowość ta jest niezależna od zmiany parametrów roboczych silnika i jest cechą charakterystyczną podziału dawki paliwa ciekłego. Równocześnie większym kątom opóźnienia towarzyszą mniejsze wartości $(\mathrm{dQ} / \mathrm{d} \alpha)_{\max }$, a różnice powiększają się wraz ze wzrostem obciążenia silnika.

Mniejsze wartości $(\mathrm{dQ} / \mathrm{d} \alpha)_{\text {max }}$ dla dawek dzielonych mają wpływ na ilości tworzonego NO w spalinach, a tym samym wpływają na zmniejszenie stężenia $\mathrm{NO}_{x}$ co sygnalizowano we wcześniejszych publikacjach $[11,16,18]$. Na podstawie zmian wartości $(\mathrm{dQ} / \mathrm{d} \alpha)_{\max }$ nie można jednak bezpośrednio wnioskować o emisji $\mathrm{NO}_{\mathrm{x}} \mathrm{z}$ uwagi na fakt, że NO tworzy się bezpośrednio za strefą płomienia (lokalnie), podczas gdy $\mathrm{dQ} / \mathrm{d} \alpha$ wyliczane jest z globalnych efektów ciepła przejętego przez cały ładunek. Mimo tego należy jednak uznać, że związek między wartościami $(\mathrm{dQ} / \mathrm{d} \alpha)_{\max }$ i emisją $\mathrm{NO}_{\mathrm{x}}$ istnieje i dla spalania w silniku dwupaliwowym wart jest rozeznania.

Podział dawki ON powoduje zmniejszenie średniej temperatury czynnika podczas aktywnego spalania. Mniejsze temperatury w pierwszej fazie spalania są naturalną konsekwencją opóźnionego wydzielania ciepła, co analizowano wcześniej, ale równocześnie maksymalne temperatury czynnika $T_{\max }$ są dla dawek dzielonych mniejsze, rys. 9d. Tendencja zmniejszenia wartości $\mathrm{T}_{\text {max }}$ utrzymuje się $\mathrm{w}$ całym zakresie zmian parametrów pracy silnika.

Mimo opóźnienia spalania dodatkowej dawki względem GMP i zmian w przebiegu wydzielania ciepła co analizowano wcześniej, podział dawki korzystnie wpływa na średnią szybkość spalania ładunku w zakresie częściowych obciążeń silnika, o czym świadczy zmniejszenie całkowitego kąta spalania ładunku $\alpha_{\mathrm{sp}}$, rys. 10.

Różnice w kącie spalania $\alpha_{\text {sp }}$ przy częściowych obciążeniach wzrastają dla większych prędkości obrotowych (1600 obr/min). Zjawisko to należy uznać za bardzo korzystne, bowiem w zakresie częściowych obciążeń silnika występuje duże zubożenie mieszaniny gazowej, które determinuje szybkość i zupełność spalania w silniku dwupaliwowym. Zwiększenie szybkości spalania tej mieszaniny, o czym świadczy wzrost wartości średniej szybkości spalania wyrażony skróceniem czasu $\alpha_{\text {sp }}$, było jednym z podstawowych założeń wprowadzenia dzielonej dawki ON. 
a)

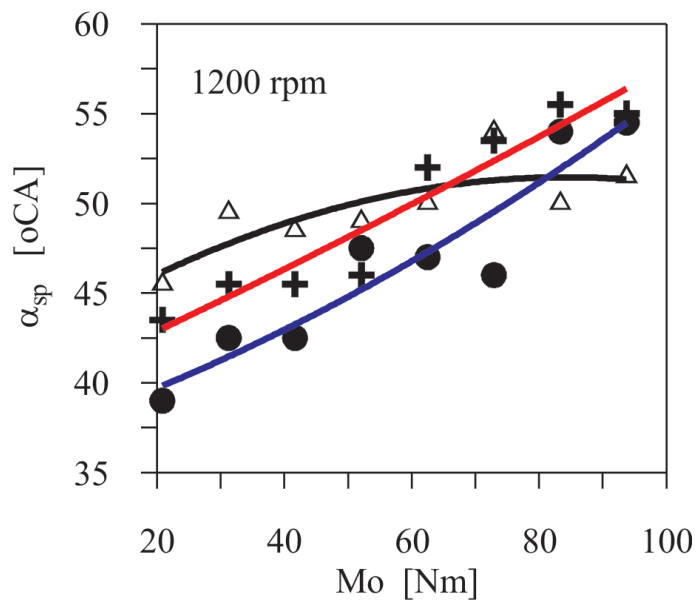

b)

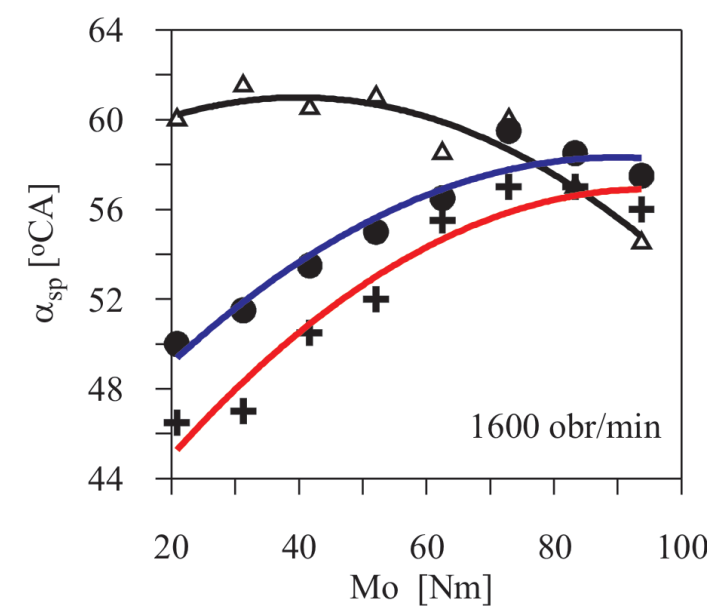

\section{Summary}

Investigations of dual fuel engine of the SB3.1 type with divided dose of the Diesel oil show the following observations, which can be utilized in other engine types adapted to dual fuel feeding.

Advantageous effects of division of the dose can include:

- Increase of overall efficiency of the engine in complete range of changing parameters of the engine. At moderate delay of the additional dose of $10{ }^{\circ} \mathrm{CA}$, relative growth of the efficiency amounted to $5-8.5 \%$, what should contribute to significant reduction of energy consumption in traction engines.

- Improvement of engine smoothness and reduction of its external noisiness. Noisiness of combustion process was twice lower with respect to the engine with single dose and close to the noisiness of spark ignited engines.

- Reduction of maximal cylinder pressure and temperature of exhaust gases, what should contribute to increase of engine durability.

- Increase of average combustion rate of the charge in area of low engine loads. Such phenomenon should be recognized as very advantageous, because in area of partial loads is present a big leaning of the gaseous mixture, which deter-

\author{
Injection timing $\theta_{\text {ww }}=22^{\circ} \mathrm{CA}$ for TDC \\ kąt wyprzedzenia wtrysku $\theta_{w w}=22^{\circ} \mathrm{OWK}$ przed GMP
}

Injection dose quantity/wielkość dawki inicjującej: $1200 \mathrm{rpm}-\mathrm{q}=33.3 \mathrm{~mm}^{3} /$ cycle $1600 \mathrm{rpm}-\mathrm{q}=28.8 \mathrm{~mm}^{3} /$ cycle

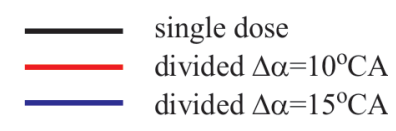

Fig. 10. Effect of division of the initial dose on combustion angle $\alpha_{\mathrm{sp}}$ in the SB3.1 engine run in dual fuel system with natural gas CNG and Diesel oil: various engine revolution $1200,1600 \mathrm{rpm}$

Rys. 10. Wplyw podziału dawki inicjującej na całkowity kąt spalania $\alpha_{s p}$ w silniku SB3.1 zasilanym dwupaliwowo gazem ziemnym $C N G$ i ON: zmienne prędkości obrotowe 1200, $1600 \mathrm{obr} / \mathrm{min}$

Równocześnie należy zauważyć, że dla obciążeń większych, zbliżonych do maksymalnego, podział dawki może nieznacznie wydłużyć proces spalania o czym świadczą przebiegi pokazane na rys. 10. Warto jednak zaznaczyć, że wydłużenie kąta $\alpha_{\text {sp }}$ nie wpłynęło negatywnie na sprawność ogólną silnika, która w zakresie tych obciążeń wzrosła, jak również na temperatury spalin po otwarciu zaworu wylotowego.

\section{Podsumowanie}

Z badań dwupaliwowego silnika SB3.1 z dzieloną dawką oleju napędowego wynikają następujące spostrzeżenia, które mogą być wykorzystane w innych silnikach adoptowanych do zasilania dwupaliwowego:

Do korzystnych skutków podziału dawki można zaliczyć: - Wzrost sprawności ogólnej silnika w całym zakresie zmian parametrów silnika. Przy umiarkowanym opóźnieniu dawki dodatkowej $10{ }^{\circ} \mathrm{OWK}$ wzrost względny sprawności wynosił 5-8,5\% co powinno przyczynić się do istotnego zmniejszenia zużycia energii w silnikach trakcyjnych.

- Poprawa równomierności pracy silnika i zmniejszenie jego hałaśliwości zewnętrznej. Hałaśliwość procesu spalania była dwukrotnie mniejsza w stosunku do silnika $\mathrm{z}$ pojedynczą dawką i zbliżona do hałaśliwości silników z zapłonem iskrowym. 
mines rate and completeness of combustion of the charge in dual fuel engine.

- Considerable reduction of $\mathrm{NO}_{\mathrm{x}}$ concentration in exhaust gases with maintained, and even increased, growth of overall efficiency of the engine [19]. Reduction of $\mathrm{NO}_{x}$ concentration amounted to $20-40 \%$ for delay of additional dose of $10^{\circ} \mathrm{CA}$ and $40-65 \%$ delay of $15{ }^{\circ} \mathrm{CA}$.

To disadvantageous phenomena connected with division of the dose can be included:

- Slight growth of CO and THC concentrations in exhaust gases [19].

- Limited possibility of division of the dose at low values of total dose due to stable operation of injectors. From such reason, when standard injectors are used, minimal dose in case of the division should be increased with about $50 \%$.
- Zmniejszenie ciśnienia maksymalnego w cylindrze i temperatury spalin co powinno przyczynić się do zwiększenia trwałości silnika.

- Zwiększenie średniej szybkości spalania ładunku w zakresie małych obciążeń silnika. Zjawisko to należy uznać za bardzo korzystne, bowiem w zakresie częściowych obciążeń występuje duże zubożenie mieszaniny gazowej, które determinuje szybkość i zupełność spalania ładunku w silniku dwupaliwowym.

- Znaczące zmniejszenie stężenia $\mathrm{NO}_{\mathrm{x}} \mathrm{w}$ spalinach przy zachowaniu, a nawet wzroście sprawności cieplnej silnika [19]. Zmniejszenie stężenia $\mathrm{NO}_{\mathrm{x}}$ wynosiło $20-40 \%$ dla opóźnienia dodatkowej dawki $10{ }^{\circ} \mathrm{OWK}$ i 40-65\% dla opóźnienia $15^{\circ} \mathrm{OWK}$.

Do niekorzystnych zjawisk związanych z podziałem dawki należy zaliczyć:

- Nieznaczny wzrost stężenia CO i THC w spalinach [19].

- Ograniczone możliwości podziału dawki przy małych wartościach dawki sumarycznej ze względu na stabilną pracę wtryskiwaczy. Z tego powodu przy zastosowaniu standardowych wtryskiwaczy minimalną dawkę przy podziale należy powiększyć o ok. $50 \%$.

\section{Bibliography/Literatura}

1. Badr O., Karim G.A., Liu B.: An examination of the flame spread limits in a dual fuel engine. Applied Thermal Engineering 19(1999) 1071-1080, 1999.

2. Saito H., Sakurai T.: Study on Lean Burn Gas Engine Ignited by Pilot Fuel Injection (Part 3). Annual Technical Report Digest Vol. 9, 1999.

3. Luft S.: Analiza wpływu dławienia powietrza zasysanego w dwupaliwowym silniku ZS zasilanym parami metanolu na jego parametry eksploatacyjne. Journal of Kones Internal Scientific Conference on Combustion Engines KONES'97, 1997.

4. Stelmasiak Z., Larisch J., Gilowski T., Matyjasik M.: Możliwości poprawy składu mieszaniny gazowej przez dławienie powietrza przy częściowych obciążeniach silnika dwupaliwowego. Archiwum Motoryzacji nr 1, s. 43-57, 2007.

5. Stelmasiak Z., Larisch J., Gilowski T., Matyjasik M.: The optimization of combustion process in a dual fuel engine with Common Rail and gas injection systems. International Congress on Combustion Engines PTNSS KONGRES-2007 „THE DEVELOPMENT OF COMBUSTION ENGINES”, 2007.

6. Matyjasik M.: Aktywizacja procesu spalania mieszaniny gazpowietrze w silnikach dwupaliwowych przez podział dawki inicjującej oleju napędowego. Praca doktorska, Bielsko-Biała 2012.

7. Pietras D.: Evaluation the sound pressure level of the small CI engine. Combustion Engines SC1 (Powertrain, Design, Ecology\&Diagnostics) 2009, s. 204-207.

Zdzisław Stelmasiak, DSc, DEng. - Professor in the Faculty of Mechanical Engineering and Computer Sciences at Technical University of Bielsko-Biala. Dr hab, inż. Zdzistaw Stelmasiak - profesor na Wydziale Budowy Maszyn i Informatyki Akademii Techniczno-Humansitycznej w Bielsku-Biatej. e-mail: zstelmasiak@ath.bielsko.pl

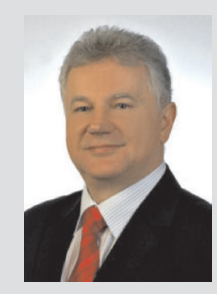

8. Pietras D., Gilowski T., Knefel T.: A program to analyze the combustion process in diesel engine. Combustion Engines No. 3/2011 (146), ISSN 0138-0346.

9. Pietras D.: Evaluation of the fuel dose distribution on the combustion process in a small diesel engine. Combustion Eengines No. 3/2011 (146), ISSN 0138-0346.

10. Liu Z., Karim G.A.: The Ignition Delay Period in Dual Fuel Engines. SAE Paper 950466, 1995.

11. Birch S.: Diesel: The fuel of the future. Automotive Engineering. May 2002.

12. Beroun S., Martins J.: The Development of Gas (CNG, LPG and H2) Engines for Buses and Trucks and their Emission and Cycle Variability Characteristics. SAE Paper 2001-01-0144.

13. Stelmasiak Z.: The Combustion Controlling in the Dual Fuel CI Engine by Pilot Dose Division. Combustion Engines No $3 / 2011$.

14. Stelmasiak Z.: Possibility of Improvement of Some Parameters of Dual Fuel CI Engine by Pilot Dose Division. Journal of Polish Cimac, Vol. 6 No. 1, pp. 181-189, 2011.

15. Stelmasiak Z., Matyjasik M.: Możliwości wykorzystanie dwupaliwowego silnika ZS zasilanego głównie gazem ziemnym CNG w transporcie kołowym. Logistyka nr 3/2012.

16. Daisho Y., Takahashi K.: Controlling Combustion and exhaust emissions in a direct-injection diesel engine dual fueled with natural gas. SAE Paper 952436, 1995.

17. Stelmasiak Z., Matyjasik M.: Simulation of the combustion in a dual fuel engine with a divided pilot dose. Combustion Engines nr 4 (151), s. 43-54, 2012.

18. Stelmasiak Z.: Studium procesu spalania gazu w dwupaliwowym silniku o zapłonie samoczynnym zasilanym gazem ziemnym i olejem napędowym. Wydawnictwo ATH w BielskuBiałej, Rozprawy naukowe Nr 5, Bielsko-Biała, 2003.

19. Stelmasiak Z., Matyjasik M.: Exhaust emissions of dual fuel self-ignition engine with divided dose. Combustion Engines No. $3 / 2013$. 